\title{
Aktiv lytning i ph.d.-vejledning - et værktøj til udvikling af dialogiske kompetencer
}

Mirjam Godskesen, lektor, Aalborg Universitet, Institut for Læring og Filosofi.

Gitte Wichmann-Hansen, lektor, Aarhus Universitet, Center for Undervisning og Læring.

\section{Reviewet artikel}

Begge forfattere har mange års erfaring med udvikling og afholdelse af kurser om ph.d.-vejledning og interesserer sig for, hvordan vejledningspraksis bedst udvikles og forandres. I denne artikel stilles der skarpt på, hvordan man kan forstå aktiv lytning som ét blandt mange elementer $i$ ph.d.-vejledningsprocessen, og i hvilken grad metoden kan understøtte udvikling af ph.d.-vejlederens dialogiske kompetence. Der rapporteres udvalgte hovedresultater fra et evalueringsstudie, som nyligt er blevet gennemført blandt deltagere fra syv ph.d.-vejledningskurser afholdt på DTU $i$ perioden 2010-2012. I lyset heraf diskuteres hoorfor vejlederne er så optagede af aktiv lytning, og hoad der kan forklare metodens popularitet.

\section{Indledning}

Litteraturen om ph.d.-vejledning fremhæver vigtigheden af, at vejledere udvikler dialogiske kompetencer (Wisker et al., 2003b; Donald, 2005; Spear 2000), og det er velbeskrevet, at graden og karakteren af lytning afspejler vejledernes grundlæggende syn på samarbejdsrelationen (Handal og Lauvås, 2006; Haksever \& Manisali, 2000). Handal \& Lauvås (2006, s. 105-6) understreger, at jo mere symmetrisk en relation man ønsker at opbygge og jo mere magtfrit et samarbejdsrum, man ønsker at etablere, jo mere vil vejledningen bære præg af dialog, hvor begge parter spørger og svarer, og hvor man sammen udforsker muligheder og tolkninger. Dysthe \& Samara (2006) tager samme position, når de opstiller tre vejledningsmodeller (undervisermodellen, partnerskabsmodellen og lærlingemodellen), der repræsenterer grundlæggende forskellige syn på samarbejdsrelationen, og som hviler på forskellige kommunikative paradigmer. Et centralt budskab i Dysthes og Samaras studie er, at de fleste vejledere uanset niveau og fag har en tendens til at agere i en "undervisermodel", dvs. at tale og rådgive meget af tiden, selvom de har en opfattelse af (og et ønske om) at agere mere partnerskabsorienteret, dvs. at skabe mere dialog i vejledningen. Ifølge forfatterne vælger tilsvarende mange studerende at acceptere en undervisermodel og indirekte efterspørge den, fordi det er et tilvant mønster fra 
tidligere skolegang (Dysthe \& Samara, 2006, s. 235). Budskabet understøttes af andre forfattere, der viser, at vejledere har en tendens til at praktisere vejledning ud fra den model, de selv har oplevet i vejledning (Lee \& Williams, 1999) og derfor ofte mangler ideer og metoder til at udvide deres repertoire af vejledningsstrategier (Lee, 2008).

Vi har gennem mange års arbejde som undervisere på ph.d.-vejledningskurser gjort os tilsvarende erfaringer. Øvelser, opgaver og diskussioner på kurserne viser, at vejledernes samtaler med studerende generelt er præget af monologer, hvor vejlederne ikke blot taler det meste af tiden men også "ejer" initiativet til at tale og styre kommunikationen. Et stort flertal af vejlederne på kurserne giver udtryk for, at de ønsker at invitere de studerende ind som mere ligeværdige samtalepartnere, men at de finder det svært at bryde med en vant vejledningspraksis.

Det er samtidig vores erfaring, at vi med stor succes har adresseret dette behov hos vejlederne ved at arbejde med aktiv lytning som en konkret metode på kurserne. Vejlederne deltager altid med stort engagement i øvelserne om aktiv lytning og fremhæver det spontant som meget værdifuldt i både de mundtlige og skriftlige evalueringer af kurserne. Erfaringen understøttes af resultater fra et evalueringsstudie, som vi nyligt har gennemført blandt deltagere fra syv ph.d.-vejledningskurser afholdt på DTU i perioden 2010-2012. I artiklen rapporterer vi udvalgte hovedresultater fra studiet og diskuterer i lyset heraf, hvorfor vejlederne er så optagede af aktiv lytning, og hvad der kan forklare metodens popularitet.

Artiklen er struktureret, så vi gennem de forskellige afsnit giver svar på de spørgsmål, som vi har stillet undervejs i arbejdet med at udvikle og gennemføre aktiv lytning som et indholdselement på vejledningskurserne. Det gøres på baggrund af litteratur om ph.d.-vejledning og aktiv lytning og gennem analyse af data fra evalueringsstudiet:

1. Hvordan kan aktiv lytning indgå på ph.d.-vejledningskurser?

2. Hvordan kan aktiv lytning forstås og meningsfuldt anvendes som en metode i ph.d.-vejledning?

3. I hvilken udstrækning oplever vejlederne, at kurserne bidrager til udvikling og forandring af deres praksis?

4. Hvad kan forklare, at vejlederne fremhæver aktiv lytning som en særlig værdifuld metode?

\section{Hvordan kan aktiv lytning indgå på ph.d.-vejledningskurser?}

Som beskrevet ovenfor, giver litteraturen solide argumenter for at fokusere på kommunikative kompetencer som et blandt flere centrale læringsmål på pædagogiske kurser for ph.d.-vejledere. Som undervisere på feltet har vi begge fulgt argumenterne og udviklet en række forskellige programflader, der adresserer kommunikation i 
ph.d.-vejledning. Én af programfladerne omhandler aktiv lytning og har været en fast bestanddel af de ph.d.-vejlederkurser, der har været afholdt på DTU i perioden 2010-2012. Uddannelsestilbuddet for ph.d.-vejledere på DTU består af to principielt uafhængige moduler: Et indledende 1-dags modul om regelsæt, forventningsafstemning og projektledelse og et videregående modul på én hel og to halve dage med titlen "Ph.d.-vejledningsprocessen: Metoder og værktøjer". Her er fokus på relationen og samarbejdet mellem ph.d.-studerende og vejleder og andre nære samarbejdspartnere, og de centrale emner i kurset er aktiv lytning, vejledningsmodeller, den ph.d.-studerendes perspektiv, spørgsmålstyper, forventningsafklaring, peer-coaching, feedback-teknikker og multikulturel vejledning. Hertil kommer præsentation af cases fra deltagerne. Aktiv lytning er bevidst valgt som det første emne, der undervises i, fordi det skaber opmærksomhed på kommunikationen, og fordi det - som en 'sidegevinst'- fremmer en mere lyttende måde at deltage i kurset på efterfølgende. Der er afsat knapt 2 timer til aktiv lytning, hvoraf 30 min. bruges på introduktion til begrebet og forklaring af øvelsen, 1 time til øvelsen i grupper af 3 personer og 15-30 min. på opsamling og diskussion i plenum.

\section{Hvordan kan aktiv lytning forstås og meningsfyldt anvendes som en metode $\mathbf{i}$ ph.d.-vejledning?}

Selvom litteraturen om ph.d.-vejledning vedholdende understreger vigtigheden af, at vejledere er opmærksomme på deres kommunikation, er der begrænset hjælp at hente i litteraturen, hvis man ønsker konkrete anvisninger på metoder til at drive en god dialog eller anbefalinger af, hvilke kompetencer det kræver af vejlederne, og hvordan de bedst udvikles. Den seneste internationale og mest omfattende håndbog om ph.d.-vejledning, skrevet af en af feltets førende forfattere Gina Wisker (2012), har et lille kapitel om "Supervisory Dialogues" på 16 sider ud af bogens i alt 567 sider. Wisker bruger hovedparten af kapitlet til at argumentere for vigtigheden af, at vejledere agerer dialogisk. Desværre er det eneste råd vejledere får til, hvordan de kan efterleve det i praksis, at de skal "identificere deres egen stemme og udtryk, når de beslutter, hvordan de vil interagere med studerende" (Wisker, 2012, s. 196). ${ }^{1}$ Læseren efterlades med et brændende ønske om mere konkrete svar på, hvad det fx vil sige at "være ligeværdige samtalepartnere" og blive "bedre til at lytte". I den seneste danske bog om universitetspædagogik er det muligt at finde svar på nogle af spørgsmålene (Wichmann-Hansen \& Jensen, 2013, s. 337-47), men generelt findes svarene mest udfoldet $\mathrm{i}$ andre områder af litteraturen end den universitetspædagogiske. Aktiv lytning er en dialogisk metode, der har vundet stor udbredelse de seneste årtier. Der findes i dag referencer til metoden inden for så forskellige områder som ledelse (IBC ledelse og HR, 2013), selvledelse (Covey, 2009), arbejdsmiljø/stressforskning (Kubota,

\footnotetext{
${ }^{1}$ Wisker opremser 11 interaktionskategorier på s. 196-98 og giver eksempler på kategorierne. Men det er uklart, både hvor disse kategorier kommer fra, og hvordan de skal bruges.
} 
2004), coaching (Whitworth et al., 1997; Prehn \& Gørtz, 2008; Molly m.fl., 2008; Gjerde, 2006; Whitmore, 2009), forskellige former for terapi (Hafen \& Crane, 2003), uddannelses- og erhvervsvejledning (Egan, 2002; Peavy, 2012), deltageraktiverende undervisning (Race, 2006; Bligh, 2000; Christensen, 1991), interviewteknik i forskningssammenhænge (Kvale, 1997), medicinsk konsultation (Robertson, 2005) og salg (Drollinger, 2006). Til brug for vores undervisning i emnet på ph.d.-vejledningskurser, trækker vi primært på litteraturen om aktiv lytning inden for ledelse, selvledelse og coaching. Begrundelsen er, at metoden inden for disse områder bruges til at håndtere udfordringer, der kan genkendes i ph.d.-vejledning.

Hvad er aktiv lytning?

Aktiv lytning blev oprindelig udviklet i terapeutisk sammenhæng (Rogers, 1959) og har rødder tilbage til organisationspsykologisk forskning i 1950'erne (Kolb m.fl., 1979). Ifølge Rogers \& Farson (1957) er aktiv lytning én ud af mange måder at lytte på, og formålet med aktiv lytning er at hjælpe andre mennesker til at udfolde sig og opnå nye erkendelser.

Lytterens åbenhed beskrives som et kardinalpunkt i litteraturen om aktiv lytning. Det vil sige, at man lytter med nysgerrighed og respekt og forsøger at lægge sine egne antagelser, værdier og dagsordenener til side. Men det bliver samtidig fremhævet som et vanskeligt krav, som mange har svært ved at efterleve. Udfordringen er, at man risikerer at forandre sit syn på verden, når man virkelig lytter med åbent sind. Rogers \& Farson (1957) formulerer dette meget præcist:

"If we permit ourselves to listen our way into the life of a person we do not know or approve of - to get the meaning that life has for him - we risk coming to see the world as he sees it. We are threatened when we give up even momentarily, what we believe and start thinking in someone else's terms. It takes a great deal of inner security and courage to be able to risk one's self in understanding another"(p.13).

Hovedbudskabet er, at mange lyttere udfordres af utålmodighed, af 'lyst til at hjælpe' og behovet for at holde fast i egen sikker grund. Som lytter kan det være en hjælp at fokusere på sin 'oprindelige' nysgerrighed - som om man ser verden (og fortællerens erkendelsesproces) for første gang. Ifølge Rogers \& Farson (ibid.) er det ofte tilsvarende vanskeligt for den, der bliver vejledt, at skulle åbne sig for nye erkendelser og integrere dem i sit verdensbillede. Det er et almenmenneskeligt træk at yde modstand, hvis man oplever, at en anden person forsøger at forandre eller overbevise én. Især hvis det truer ens selvbillede. Ideelt må begge parter således kunne tilsidesætte behovet for at overbevise den anden, hvis der virkelig skal være tale om aktiv lytning. 
Foruden åbenhed og nysgerrighed er opmærksomhed også et centralt princip i aktiv lytning, hvilket især fremgår af markøren 'aktiv'. Aktiv og passiv lytning er et centralt begrebspar i litteraturen (Rogers \& Farson, 1957). Begrebet 'aktiv' indebærer, at lytteren gør mere end blot passivt at absorbere de ord, der siges. Det indebærer at udtrykke sin opmærksomhed og empati, at lytte bevidst ved brug af flere forskellige dialogiske greb og tilpasse dem til den konkrete situation. Et væsentligt aspekt er, at man lytter og responderer både på ordene og på det følelsesmæssige niveau. I nedenstående figur har vi opsummeret og eksemplificeret konkrete anvisninger for praktisering af aktiv lytning, på tværs af de udvalgte litteraturområder:

\author{
Opmærksomhed og tålmodighed \\ - Lytte opmærksomt, dvs. ikke kigge ud ad vinduet eller på computeren. \\ - Holde kontakt og være bevidst om sine måder at respondere på. \\ - Undgå at afbryde. \\ - Giv tænketid (også) når fortælleren holder pauser \\ - Øve sig i at kunne rumme stilhed. Her kan man bruge såkaldte "drive-teknikker" \\ som fx at nikke og sige: Hmm..., Nåeh,...
}

Respondere på både ord og følelser

- Høre både det der bliver sagt og aflæse og reagere på de non-verbale signaler, der kommunikeres.

Fx: Fortæller: "Jeg er ikke er nået så langt, som jeg gerne ville"

- Lytter: "Har du haft meget travlt i den sidste tid?"

Agere åbent og nysgerrigt

- Stille åbne og uddybende spørgsmål.

Fx: "Hvilke andre muligheder kunne du forestille dig?", "Hvilken løsning tror du selv mest på?" eller "Hvad kunne fordelene være ved at gøre det på den måde?"

- Pas på med "tilsyneladende" åbne spørgsmål. Fx: "Ville det så ikke være spændende at gå videre med fx X?"

- Som lytter kan det være en hjælp at fokusere på sin egen nysgerrighed overfor fortælleren og emnet i samtalen.

Fx: "Hvordan opfatter du begrebet tillid?" eller "hvad er din erfaring med den type DNA-analyser?"

Vise respekt ved at teste egen forstålse gennem reformulering

- Genfortælle mening i det man har hørt og undersøge om man har forstået det rigtigt.

- Fx: "Som jeg forstår det, så har du mest tiltro til at gå videre med projektdel X, fordi vi allerede har proceduren klar. Er det rigtigt forstået?"

Figur 1. Elementer i aktiv lytning med uddybning og eksempler 
I hvilken udstrækning oplever vejlederne at kurserne bidrager til udvikling og forandring af deres praksis?

Vi har indtil nu opstillet teoretiske argumenter for at undervise ph.d.-vejledere i aktiv lytning, ligesom vi har redegjort for, hvordan teorierne kan "oversættes" til konkrete principper og metoder. Men finder vejlederne reelt emnet interessant og nyttigt som redskab til at (videre-) udvikle deres praksis? Nedenfor beskriver vi metoder og resultater fra vores evalueringsstudie, der havde til formål at indsamle systematisk viden om vejledernes udbytte af kurserne.

Metode

Vi udsendte primo 2013 et elektronisk spørgeskema til samtlige vejledere $(\mathrm{N}=86)$ der havde deltaget i de syv kurser afholdt på DTU i perioden 2010-12. Skemaet indeholdt en kombination af lukkede og åbne spørgsmål i 4 kategorier: 1) Baggrundsspørgsmål (hvor mange ph.d.-studerende de har vejledt og hvor længe det er siden, de har haft kurset); 2) hvordan de i dag vurderer udbyttet af kurset; 3) for hvert af 9 kursuselementer spørges der til, a) om de kan huske det? (lukket spm.) b) om de har brugt det i praksis (lukket spm.), c) om de kan give eksempler på deres brug af kursuselementet i deres vejledning (åbent spm.); 4) vil de anbefale kurset og hvilke yderligere ønsker har de til kompetenceudvikling i relation til vejledning. Svarprocenten var $63 \%$ $(\mathrm{N}=54)$. Vi fokuserede på den del af undersøgelsen, der handler om aktiv lytning. Empirien består af 26 eksempler, som vejlederne giver på deres egen brug af aktiv i praksis, og fylder samlet næsten to siders tekst, som er analyseret ved brug af tematisk analyse (Braun \& Clarke, 2006).

\section{Resultater}

Aktiv lytning er det kursuselement, flest deltagere husker: På spørgsmålet om, hvilke af de 8 elementer fra kurset, de kan huske, svarer 92\%, at de kan huske "aktiv lytning". Til sammenligning svarer $85 \%$, at de kan huske emnet om "vejleder-roller og vejledningsstil", og 77\% husker, at de lærte om "konstruktiv feedback". Efterfølgende spørges, om de har anvendt aktiv lytning i praksis i deres ph.d.-vejledning, og det bekræfter $85 \%$ af respondenterne, og 26 af dem (49\%) giver derefter konkrete eksempler på, hvordan de i dag bruger aktiv lytning i deres vejledning.

Fire af vejlederne beskriver aktiv lytning som et naturligt element i deres vejledning eller som noget, de allerede "har implementeret". "I use it all the time for all subjects ... its hard not to use", siger én af respondenterne. Her kan være tale om vejledere, der allerede praktiserede aktiv lytning som en naturlig del af deres vejledning, inden de deltog i vejlederkurset, men det kan også være, at de netop har lært tilstrækkeligt på kurset, så de nu mestrer teknikken. 
Langt hovedparten af respondenterne beskriver derimod aktiv lytning som noget de forsøger at blive bedre til. Vendingerne "I try to...", "I attempt to..." eller "I aim at..." indgår i 19 ud af de 26 svar, hvilket indikerer, at aktiv lytning fremstår som en dialogisk form, de løbende er opmærksomme på og stræber mod at opnå i deres vejledning. Gennem den tematiske analyse fandt vi fem forskellige kommunikative udfordringer, som vejlederne forsøgte at blive bedre til at håndtere ved at bruge forskellige aspekter af aktiv lytning.

Hvilke udfordringer forsøger vejlederne at løse med aktiv lytning?

I eksemplerne på, hvordan aktiv lytning anvendes, beskriver 19 ud af 26 respondenter, hvad de stræber efter at opnå med aktiv lytning. Det viser sig, at de fremhæver følgende fem aspekter (hvor nogen dog nævner flere aspekter i deres eksempler):

1) Otte af vejlederne fremhæver, at de arbejder på at undgå at snakke for meget selv, ikke afbryde den ph.d.-studerende eller overtage dialogen. "I try to do it [active listening] but it is really hard for me to not "start talking". Practice!!", skriver en af respondenterne.

2) Fem vejledere har fokus på at facilitere den studerendes egen tænkning og læring, hvilket fremgår tydeligt af følgende citat: "I try not just to answer questions, but rather return a question into a new question or at least initiate a discussion. This is in order to make the PhD student think, and not only ask questions."

3) Fem vejledere fremhæver det tredje aspekt, som er at de er blevet mere opmærksomme på at sikre sig, at de virkelig har forstået den ph.d.-studerendes spørgsmål og udfordringer. "Every time I talk to the student, I now have in mind that I should try and understand what he/she is really asking, even if sometimes I think I know the answer after just a few words." Denne opmærksomhed i forhold til at give sig tid til at forstå den studerendes tanker og overvejelser er tæt knyttet til det fjerde aspekt.

4) Der er tre vejledere, der nævner det fjerde aspekt, som handler om ikke at give gode råd for hurtigt. "I try to let the student talk and formulate the problems/issues and their solution instead of giving my answers right away," formulerer en af vejlederne.

5) Endelig er der fem vejleder, der giver eksempler på det aspekt, som vi tidligere i artiklen benævnte "at respondere på både ord og følelser". "I am more actively trying to "read" the person as well as listen to what they say, for example it has helped in detection and reduction of stress for one of my students". De beskriver det aspekt, der handler om at have en øget opmærksomhed på den ph.d.-studerendes tilstand og processen, som "at læse personen" eller at "læse mellem linjerne". 
Eksemplerne viser, at vejlederne har fået nogle klare opmærksomhedspunkter i forhold til deres kommunikationsform, og at det er blevet muligt for dem at skelne mellem mere eller mindre kvalificerede måder at lytte på. Alle 26 vejledere siger positivt, at de bruger aktiv lytning i deres vejledning, men samtidig viser eksemplerne, at det er noget de stadig arbejder på at blive bedre til og ikke føler sig gode nok til. Det kan betyde, at de på kurserne har fået redskaber til i stigende grad at kunne anvende og udvikle aktiv lytning, og at de er motiverede til at gøre det, men at det kræver en del øvelse og måske også mere træning, før det bliver en integreret og naturlig del af deres individuelle vejledningspraksis.

\section{Diskussion: Hvad kan forklare, at aktiv lytning er den metode, der står stærkest $\mathbf{i}$ vejledernes bevidsthed og praksis efter kurset?}

Resultaterne af evalueringsstudiet viser, at undervisning i og træning af aktiv lytning på vejlederkurser giver vejlederne en kompetence til at bruge forskellige dialogiske elementer som en del af deres vejledningsrepertoire. De dialogiske elementer i aktiv lytning artikuleres stadig meget præcist op til 3 år efter kurset er afsluttet. Vi konkluderer derfor, at undervisningen i aktiv lytning har gjort et stort flertal af vejlederne mere bevidste om, hvilke dialogiske elementer de tager i brug, hvornår og hvorfor. Men hvad kan forklare metodens succes?

En væsentlig forklaring kan være, at metoden initierer forandring både fra et vidensplan og et handlingsplan på samme tid. Det er med andre ord ikke nok at erkende, at man gerne vil være en mere partnerskabsorienteret vejleder, man skal også øve det i praksis. Metoderne og indstillingen hænger uløseligt sammen og hvis man forsøger at anvende metoderne uden at arbejde med indstillingen, vil det formentlig opleves akavet og utroværdigt (Fibæk, 2004). Lytteøvelserne på kurset fordrer, at vejlederne afprøver det at skulle lytte og nysgerrigt spørge ind til den andens perspektiv. Efterfølgende får de feedback på deres aktive lytning og de bliver opmærksomme på betydningen af deres indstilling til samtalepartneren. Ofte opdager de, at de er mere interesserede $i$ at løse den andens problemer, end de er i at forstå den andens perspektiv og hjælpe vedkommende med at finde sine egne løsninger. Denne erkendelse virker positivt ind på deres lyst til at forfine teknikken.

En anden mulig forklaring er, at aktiv lytning rummer en række principper, som reelt har et ærinde og en relevans i en akademisk faglig sammenhæng på trods af, at de er taget fra en terapi-, ledelses-og coachingsammenhæng. Eksempelvis er der klare paralleller mellem det stærke fokus på processtøtte inden for ledelse og selv-ledelse og behovet for processtøtte i ph.d.-vejledning. Et ph.d.-studie er mere end et forskningsarbejde. Det er også et læringsarbejde. Ph.d.-vejlederen skal derfor optimalt kunne støtte den ph.d.-studerende både i forhold til den faglige udvikling og i forhold til lære- og studieprocessen. Ønsket er, at den studerende udvikler tiltro til 
sine egne kompetencer, styrker sin refleksion over eget arbejde og egen læring for på sigt at kunne træffe mere sikre, velovervejede beslutninger (Wisker, 2012, s. 36). Ligesom det er en særlig pointe inden for ledelse, at aktiv lytning er en "investering" $i$ at udvikle medarbejderes selvstændighed, kan man hævde, at det inden for ph.d.vejledning er en investering at udvikle den studerendes følelse af ejerskab og råderum. Det, der tager tid på den korte bane, er effektivt på den lange bane.

Trods disse lighedstræk, så foregår ph.d.-vejledning i en særlig kontekst, som gør, at aktiv lytning må nuanceres og anskues mere komplekst, hvilket vi lægger stor vægt på at understrege på kurserne.

For det første kan coaching-terminologien virke svær at applicere. Når der fx tales om det "følelsesmæssige niveau", kan det let give associationer til terapeutiske samtaler og en type vejlederrelation, der er mere tæt og privat, end hvad de fleste vejledere ønsker. Men hvis man oversætter det til "at være opmærksom på det der siges mellem linjerne", den ph.d.-studerendes motivation og vedkommendes reaktioner, som udtrykkes gennem kropssproget, kan det give mere mening i en akademisk vejledningskontekst. Som det fremgik af resultaterne fra evalueringsstudiet, fremhæver fem af de vejledere, der gav eksempler på deres brug af aktiv lytning, netop dette aspekt af aktiv lytning som noget, de har haft gavn af i deres vejledning.

For det andet foregår ph.d.-vejledningssamtaler i et fagligt rum og i en videnskabelig diskurs med vægt på argumentation og afprøvning af påstande (Habermas, 2005). Den argumentative samtaleform kan umiddelbart synes fjern fra aktiv lytning, hvor man ikke stræber efter at overbevise den anden eller opnå enighed. Men spørgsmålet er, om de to positioner kan stilles så skarpt op overfor hinanden som modsætninger? Ifølge Rommetveit (1974) er det en misforståelse at opfatte dialog som ensbetydende med ukritisk snak og fravær af faglige holdepunkter (Rommetveit, 1974). Rommetveit (1974) påpeger, at for at dialoger kan være kreative og produktive, må de også indeholde konfrontationer og afprøvning af påstande. I faglige vejledningssammenhænge som fx ph.d.-vejledning er det nødvendigt, at vejlederen tør fremstå som en faglig autoritet og vedkende sig den asymmetri, der ligger $i$ at have mere viden. Det afgørende er, hvordan man forvalter sin merviden som vejleder. Den videnskabelige diskurs' krav om kritisk argumentation udelukker ikke, at man som vejleder møder den studerende med respekt og med en reel vilje til at lytte og forstå det, den studerende siger (Handal \& Lauvås, 2006, s. 107). Eller sagt på en anden måde: Betingelserne for aktiv lytning (åbenhed, respekt og reduceret asymmetri) er vigtige for, at vejleder og studerende sammen kan bevæge sig ud i faglige konfrontationer, men de må suppleres med den videnskabelige diskurs' krav om kritisk argumentation for at være dækkende for ph.d.-vejledning. 
For det tredje kan idealet om den lyttende, dialogorienterede vejleder synes uforenelig med det stigende krav om hurtig studiegennemførelse. I dag er tidsfrister og rammer for ph.d.-uddannelserne blevet stramme og formelle og vejledere forventes ofte at kontrollere den studerendes og projektets progression nøje og nærmest stå som garant for fremgangen og kvaliteten. Mange vejledere kan derfor føle sig presset ind i en kontrollerende og intervenerende vejlederrolle med det argument, at den lyttende vejlederrolle, hvor man er optaget af at udvikle kritiske og selvstændige studerende, er for tidskrævende og i konflikt med kravet om hurtig gennemførsel (Lee, 2008; Franke \& Arcidsson, 2010). Men igen kan man med rette stille spørgsmål ved det hensigtsmæssige $\mathrm{i}$ at opstille det som to uforenelige positioner. I litteraturen om ph.d.-vejledning er der en tendens til, at positionerne opstilles som modsætninger - som et dilemma. Et af de mest klassiske og oftest rapporterede dilemmaer i ph.d.-vejledning er dilemmaet mellem "styring og selvstyring", mellem "kontrol og frihed": Skal vejlederens krav og viden være styrende for processen og produktets kvalitet, eller skal vejlederen overlade styringen og beslutningerne til den studerende (Cantwell \& Scevak, 2004; Lee, 2008; Lovitts, 2008; Franke \& Arcidsson 2010)? Håndteringen af dilemmaet bliver ofte beskrevet som et enten/eller, hvor vejlederen enten giver tæt vejledning (hands-on) eller lader den studerende klare sig selv uden at blande sig ret meget (hands-off) (Cullen et al., 1994). Men principperne og rådene fra litteraturen om aktiv lytning synes at tilbyde en tredje vej. At være aktivt lyttende betyder, at man som vejleder støtter den ph.d.-studerende $\mathrm{i}$ at finde løsningerne selv uden at overlade den studerende til sig selv. Vejlederen holder som udgangspunkt sine gode råd og færdige løsninger tilbage. Hvis vejlederen giver råd og løsninger, er det først efter at have sat sig grundigt ind i den studerendes tanker og afdækket de handlemuligheder, som den studerende selv ser. Vejlederen er således ikke fraværende som faglig autoritet men er både optaget af at give stemme til sig selv og af at lytte og reformulere den studerendes stemme. Der er ikke tale om et enten-eller, men om at opbygge tillid og respekt over tid, så den studerende stoler på, at vejlederen er en faglig kapacitet på sit område og et menneske, der har et reelt ønske om at støtte den studerende i at udvikle sit kreative potentiale og selvstændighed.

Mirjam Godskesen er civilingeniør fra DTU, ph.d. i Teknologisociologi og lektor ved Institut for Læering og Filosofi på Aalborg Universitet. Har arbejdet som konsulent inden for coaching og forandringsledelse og stået for udviklingsprojekter omkring ph.d.-coaching og organisationsudvikling på universiteterne. Forsker i ph.d.-coaching, ph.d.-vejledning og forandringsledelse i organisationer. Udvikler kurser, vejleder og underviser $i$ ph.d.-vejledning, portfolio-metoder, projektledelse, læring og forandringsprocesser.

Gitte Wichmann-Hansen er cand.mag. i Pædagogik, ph.d. i Uddannelsesforskning og lektor ved Center for Undervisning og Læring på Aarhus Universitet. Gitte underviser og forsker i vejledning med særligt fokus på vejledning knyttet til studerendes opgave-, projekt- og forskningsforløb på universitetet. Hun afholder kurser i emnet på tværs af fakulteter og universiteter i Danmark og i Norden. Derudover indgår hun i lokale, nationale og internationale netværk om ph.d.-vejledning, og har flere internationale publikationer bag sig om især ph.d.-vejledning. 


\section{Litteratur}

Bakhtin, M. M. (1998). Spørgsmålet om talegenrane. Oversat af Rasmus Slaattelid. Bergen: Ariadne Forlag.

Bligh, D. A. (2000). What's the Point in Discussion? Exeter: Intellect.

Braun, V. \& Clarke, V. (2006). Using thematic analysis in psychology. Qualitative Research in Psychology; 3, s. 77-101.

Brew, A. T., \& Peseta, T. (2004). Changing postgraduate supervision practice: a programme to encourage learning throgh reflection and feedback. Innovations in Education and Teaching International, 41(1), s. 5-22.

Cantwell, R., \& Scevak, J. (2004). Discrepancies between the "ideal" and "passable" doctorate: Supervisor thinking on doctoral standards. Annual Conference of the Australian Association for Research in Education, Melbourne.

Christensen, C. R. (1991). The discussion teacher in action: questioning, listening, and response. In: Christensen, C. R.; Garvin, D. A. \& Sweet, A. (ed.): Education for Judgement. The Artistry of Discussion Leadership. Boston, Harvard Business School Press., s. 153-172.

Covey, S. R. (2009). Syv gode vaner. Kbh.: Gyldendal.

Cullen, D., Spearson M., Saha, L. J. \& Spear, R. H. (1994). Establishing Effective PhD Supervision. Canberra: Australian Government Publishing Service.

Donald, J. G., Saroyan, A., \& Denison, D. B. (1995). Graduate student supervision policies and procedures: A case study of issues and factors affecting graduate study. The Canadian Journal of Higher Education, XXV (3), s. 71-92.

Drollinger, T., Comer, L. B., \& Warrington, P. T. (2006). Development and validation of the active empathetic listening scale. Psychology \& Marketing, Volume 23, Issue 2, s. 161-180.

Dysthe, O., \& Samara, A.. (red). (2006). Forskningsveiledning på master- og doktorgradsnivå. Oslo: Abstrakt Forlag.

Egan, G. (2002). The Skilled Helper. $7^{\text {th }}$. Edition. Pacific Grove, CA: Wadsworth Publishing.

Franke, A., \& Arcidsson, B. (2010). Research supervisors' different ways of experiencing supervision of doctoral students. Studies in Higher Education, 36(1), s. 7-19.

Gjerde, S. (2006). Coaching - hvad, hvorfor, hvordan. Frederiksberg: Forlaget Samfundslitteratur.

Habermas, L. (2005). Teknik og videnskab som 'ideologi'. Det lille Forlag.

Haksever, A. M., \& Manisali, E. (2000). Assessing supervision requirements of PhD students: The case of construction management and engineering in the UK. European Journal of Engineering Education, 25 (1), s. 19-32.

Handal, G., \& Lauvås, P. (2006). Forskerveilederen. Oslo: Cappelen Akademisk Forlag. IBC ledelse og HR (2013). Grundlxggende lederuddannelse, http://lederuddannelse.net/Lederuddannelser/Grundlaggendelederuddannelse/grundlaeggende-lederuddannelse.html, Accessed 080113. 
Kolb, D., Rubin I., \& MacIntyre, J. (1979). Organizational Psychology (3 ${ }^{\text {rd }}$. edition). New Jersey: Prentice Hall.

Kubota, S., Mishima, N. \& Nagata, S. (2004). A Study of the Effects of Active Listening on listening attitudes of middle managers. Journal of Occupational Health, 46 (1), s. 60-67.

Kvale, S. (1997). InterView: en introduktion til det kvalitative forskningsinterview. København.: Hans Reitzels forlag.

Lee, A. (2008). How are doctoral students supervised? Concepts of doctoral research supervision. Studies in Higher Education, 33(3), s. 267-281.

Lee, A., \& Williams, C. (1999). Forged in fire: narratives of trauma in PhD supervision pedagogy. Southern Review, 32, s. 6-26.

Lovitts, B. E. (2008). The Transition to Independent Research: Who Makes It, Who Doesn't, and Why. Journal of Higher Education, Vol. 79 (3), s. 296-325.

Pearson, M., \& Brew, A. (2002). Research Training and Supervision Development. Studies in Higher Education, 27(2), s. 135-150.

Peavy, R. V. (2012). Konstruktivistisk vejledning. København: Studie og Erhverv, 3. oplag

Prehn, A., \& Gørtz, K. (2008) Coaching i perspektiv: en grundbog. København: Hans Reitzel.

Race, P. (2006). The Lecturer's Toolkit. $3^{\text {rd }}$ Edition. London: Routledge

Robertson, K. (2005). Active listening - more than just paying attention. Autralian Family Physician, 34,12.

Rogers, C. \& Farson, R. (1957). Active Listening. Chicago: Industrial Relations Center of The University of Chicago.

Rogers, C. F. (1959). A theory of therapy, personality and interpersonal relationships as developed in the client-centered framework. In S. Koch (Ed.), Psychology: A study of science, 3rd ed. (s. 184-256). New York: McGraw-Hill.

Rogers, C., \& Farson, R. (1979). Active Listening. In D. Kolb, I. Rubin, \& J. MacIntyre. Organizational Psychology (third edition). New Jersey: Prentice Hall.

Rommetveit, R. (1974). On message structure. London: John Wiley

Spear, R. H. (2000). Supervision of Research Students: Responding to Student Expectations. Canberra: The Australian National University.

Whitmore, J. (2009). Coaching for Performance. London : Nicholas Brealey Publishing Whitworth, L., Kimsey-House, H., \& Sandahl, P. (1997). Co-active coaching: new skills for coaching people toward success in work and life. Mountain View: Davies-Black Publishing

Wichmann-Hansen, G., \& Wirenfeldt Jensen, T. (2013) Processtyring og kommunikation i vejledning. In: Rienecker, L., Jørgensen, P. S., Dolin, J. \& Holten, G.I. (red.). Universitetspædagogik. Frederiksberg: Forlaget Samfundslitteratur. 
Wisker, G., Robinson G., Trafford, V., Creighton, E. \& Warnes M. (2003a). Recognising and Overcoming Dissonance in Postgraduate Student Research. Studies in Higher Education, 28(1), s. 91-105.

Wisker, G., Robinson G., Trafford, V., Warnes M. \& Creighton, E. (2003b). From Supervisory Dialogues to Successful PhDs: Strategies supporting and enabling the learning conversations of staff and students at postgraduate level. Teaching in Higher Education, 8(2), s. 383-97

Wisker, G. (2012). The Good Supervisor. West Yorkshire: Palgrave MacMillan, 2.ed. 